\title{
Comparison of physical fitness of turkish and iraqi sedentary boys
}

\section{Harun GENÇ${ }^{1}$, KaraemAli GHAZWAN 2, Gökmen KILINÇARSLAN¹}

\author{
${ }^{1}$ Bingol University of Physical Education and Sports School, Bingöl, Turkey \\ ${ }^{2}$ Libya 17fibray School / Ankara, Turkey \\ ${ }^{*}$ This paper was presented (oral presentation) at the International Congress of Sports for All and Wellness will be held in Alanya/Antalya on 5-8 \\ April 2018. \\ Address correspondenc eto H.Genc, e-mail:hgenc@bingol.edu.tr
}

\begin{abstract}
In this study, it is aimed to compare the anthropometric and physical fitness values of Turkish and Iraqi sedentary boys who were educated in 2017-2018 education year. A total of 68 boys, aged 13,60+0,60 with 35 Turkish and 13,81+0,84 with 33 Iraqi, who had no health problems and no disadvantages in entering the physical education course, participated voluntarily. Anthropometric measurements (age, height, weight, body mass index) of the boys participating in the study were taken. Eurofit Test Battery tests (flamingo balance test, sit-in flexibility test, standing long jump test, paw force test, shuttle test, twisted arm hanging test, disk touch test, $10 \times 5$ meter agility running test, and vo2 max shuttle running test). The arithmetic mean and standard deviation of all measurements are calculated. Statistical analyzes of the measurements were made in the SPSS 22 program. Regular measurement of physical fitness values, including the physical and anthropometric characteristics of secondary school children, can be used to monitor the physical fitness levels and to set national norms by arranging criteria related to the physical characteristics of students. In addition to this, it can also contribute to the healthy growth of children, to the efficient human power and to the selection of qualified athletes.
\end{abstract}

Keywords: Anthropometry, Physical Fitness, Sedanter.

\section{INTRODUCTION}

Physical fitness refers to the physical condition of the body in relation to the proper functioning of movements and physical endurance. Physical fitness depends on person's strength, endurance, coordination, quickness, and co-operation of these features(27).

Physical fitness associated with health is measured by body composition, flexibility, muscular endurance, cardiovascular endurance, and muscular strength tests. In addition to the physical fitness, the parameters associated with health, performancerelated physical fitness is measured with agility, speed, muscle strength, coordination and balance tests(1). These tests are used to assess the effects of regular physical activity on physical development and health in children and adolescents (24).

Children's physical and motor fitness skills should be of great importance not only for sports educators and health workers but also for everyone. It is seen that the children of today are more immobile and overweight and have more subcutaneous fat tissues. Considering these, the main causes are the apartment lifestyle, the lack of playground, ease of transport, ensuring children to play at home by parents for more comfortable control, spending of majority of their time out of school with Atari and computer games. It should be noted that the basis of the habits required for active life is shaped during childhood, as in other habits (14).

Assessment of the level of personal physical fitness in children and adolescents allows healthy life began at an early age, so a person's lifelong habit of exercise along with physical activity and physical fitness is gaining importance (2).

The aim of this study was to determine and compare the physical fitness levels of 35 Turkish male sedentary students $(13,60 \pm 0,60$ years $)$ and 33 Iraqi male sedentary students $(13,81 \pm 0,84$ years).

\section{MATERIALS \& METHOD}

35 Turkish and 33 Iraqi male students were selected on voluntary basis from students who had 
no health and other problems to attend physical education course.

\section{Data collection tools}

\section{Anthropometric Measurements}

Height:The height measurements of the subjects were measured by standard wall scale. Height measurements were carried out without shoes, and feet adjacent, knees stretched, while head, back,and heels were leaning against the wall and standing upright. While in this position, the height was measured with the help of a small ruler with a $90^{\circ}$ angle to the wall. Measurements were made with 0.1 cm accuracy.

Weight:The body weight of the subjects was measured using AR550 Sottile brand mediumprecision digital glass bathroom scale.

Body weight measurement was made with minimal dress and without shoes.

Body Mass Index:The weight is divided by the square of the height to obtain Body Mass Index(22).

\section{Eurofit Test Battery}

Flamingo balance test: In this test, which aims to measure general body balance, $50 \mathrm{~cm}$ long, $4 \mathrm{~cm}$ high, $3 \mathrm{~cm}$ wide, with a non-slip metal beam (thickness of up to $5 \mathrm{~mm}$ ) was used. To protect the height of the beam from the ground, $15 \mathrm{~cm}$ long and $2 \mathrm{~cm}$ wide legs were placed on both ends. The participant placed his anyone foot on the beam for one minute to stay in balance. He bent his other leg back and held his foot in the same direction. The participant tried to maintain balance in this position, when he lost his balance (when he left his leg) or when his body touched anywhere, the test and time stopped. After each fall, the participant tried to stay in balance during one minute. Any attempt to maintain the balance on the beam within one minute (except fall) was recorded as point (25).

Plate Tapping Test: On two plastic discs on the cardboard surface, and a flat surface with a rectangular plate in the middle of these two discs, the participant held one hand fixed on the rectangular plate and touched each disc 25 times with the other hand. The test was repeated twice. Best result was recorded in second (22).

Sit and Reach Test: The participant in the sitting position with both hands yawning forward and remained at the far end for 1-2 seconds. The test was repeated twice and the best grade was recorded as a result of the test(22).

Standing Long Jump Test: It is the test where theyjumps forward with double foot from the starting point. For best results, the test was applied twice. The longest distance for jumping was recorded as a test result (22).

Hand Gripping Test: In this test used for measuring the force of muscle, Takei Physical Fitness Test Grip-D (Grip Strength Dynamometer, Japan) dynamometer was used. The force of both hands was measured. Best results recorded in kilograms (kg) (22).

Sit-Up Test: Abdominal muscle strength was assessed in this test, the highest number of sit-up counts was recorded in 30 seconds for each participant (22).

10x5 Shuttle Run Test: Running speed, coordination and agility characteristics were evaluated in this test, which shows running and turning at maximum speed. The running area was determined by creating a rectangle of $1.2 \times 5$ meters. The total time was recorded in seconds (22).

\section{Data Analysis}

SPSS 22 software was used in statistical analysis of the data. The mean of the measured and tested values and the standard deviations (SD) were calculated. Statistical significance level was accepted to be $\mathrm{p}<0.05$.

\section{FINDINGS}

Table 1. A comparison of anthropometric measurements of Turkish and Iraqi boys

\begin{tabular}{|c|c|c|c|c|c|}
\hline \multirow{2}{*}{$\begin{array}{l}\text { Anthropometric } \\
\text { Tests }\end{array}$} & \multicolumn{2}{|c|}{ Turkish boys } & \multicolumn{2}{|c|}{ Iraqi Boys } & \multirow{2}{*}{$\begin{array}{l}\text { Statistical } \\
\text { Sign. (p) }\end{array}$} \\
\hline & $\mathrm{n}$ & Mean \pm S.D. & $\mathrm{n}$ & Mean \pm S.D. & \\
\hline Age (year) & 35 & $13.60 \pm 0.60$ & 33 & $13.81 \pm 0.84$ & 0.223 \\
\hline Length $(\mathrm{cm})$ & 35 & $166.22 \pm 11.34$ & 33 & $129.96 \pm 11.95$ & .000 \\
\hline Weight $(\mathrm{kg})$ & 35 & $57.77 \pm 10.71$ & 33 & $38.03 \pm 5.90$ & .000 \\
\hline Body Mass Index & 35 & $20.68 \pm 2.83$ & 33 & $23.01 \pm 5.43$ & .029 \\
\hline$p<0.05$ & & & & & \\
\hline
\end{tabular}


According to Table 1, the height and body weight from the body composition measurements were found to be significantly higher in Turkish male children than in Iraqi male children; it was determined that body mass index values were significantly higher in Iraqi boys.

Table 2. Comparison of Eurofit test results of Turkish and Iraqi boys

\begin{tabular}{|c|c|c|c|c|c|}
\hline \multirow[t]{2}{*}{ The tests } & \multicolumn{2}{|c|}{ Turkish boys } & \multicolumn{2}{|c|}{ Iraqi boys } & \multirow{2}{*}{$\begin{array}{l}\text { Statistical } \\
\text { Sign. (p) }\end{array}$} \\
\hline & $\mathrm{N}$ & Mean \pm S.D. & $\mathrm{N}$ & Mean \pm S.D. & \\
\hline Flamingo Balance Test & 35 & $10.45 \pm 3.72$ & 33 & $7.42 \pm 3.81$ & .001 \\
\hline Sit And Reach Test & 35 & $23.77 \pm 7.16$ & 33 & $17.10 \pm 7.36$ & .000 \\
\hline Sit-Up Test & 35 & $24.88 \pm 4.22$ & 33 & $23.09 \pm 5.07$ & .117 \\
\hline Standing Long Jump Test & 35 & $170.97 \pm 25.19$ & 33 & $152.09 \pm 23.01$ & .002 \\
\hline Hand Gripping Test & 35 & $24.57 \pm 4.87$ & 33 & $24.63 \pm 5.53$ & .959 \\
\hline 10x5 Shuttle Run Test & 35 & $34.97 \pm 3.49$ & 33 & $33.46 \pm 3.32$ & .073 \\
\hline Plate Tapping Test & 35 & $14.94 \pm 2.11$ & 33 & $15.74 \pm 2.74$ & .182 \\
\hline Bent Arm Hang Test & 35 & $12.71 \pm 13.70$ & 33 & $24.69 \pm 15.41$ & .001 \\
\hline Shuttle Run Test & 35 & $32.84 \pm 6.15$ & 33 & $34.08 \pm 5.05$ & .366 \\
\hline
\end{tabular}

$\mathrm{P}<0.05$

According to the Eurofit test results in Table 2, Iraqi boys were significantly more successful in Flamingo balance test and bent arm hang test than Turkish boys, and Turkish boys were more successful in sit-up test and standing long jump test than Iraqi boys. There was no statistically significant difference between the two groups in the other tests.

\section{DISCUSSION \& CONCLUSION}

In the present study, anthropometric and physical fitness values of 68 sedentary male students, including 35 Turkish and 33 Iraqi male students in 2017-2018 academic year, with an average age of 13.60 years and 13.81 years, respectively, who does not have any sportive activity other than routine physical classes, were measured and the data obtained were compared.

The anthropometric values of Turkish male students are as follows; age: $13.60 \pm 0.60$ years, body mass index: 20.68 \pm 2.83 , height: $166.22 \pm 11.34 \mathrm{~cm}$, weight: $57.77 \pm 10.71 \mathrm{~kg}$; while for Iraqi boys, the age:13.81 \pm 0.84 years, Body Mass Index: 23.01 \pm 5.43 , height: $129.96 \pm 11.95 \mathrm{~cm}$, weight: $38.03 \pm 5.90 \mathrm{~kg}$. There was no significant difference between the Turkish and Iraqi age values ( $>00.05)$. However, height and body weight were significantly higher in Turkish boys than in Iraqi boys; the body mass index was found to be significantly higher in Iraqi boys than in Turkish boys $(\mathrm{p}<0.05)$.

In a study conducted by Bilim et al. (2), the mean height of male students with an average age of $14.55 \pm 0.50$ years was $163.47 \pm 10.65 \mathrm{~cm}$, and the mean body weight was $55.83 \pm 15.28 \mathrm{~kg}$., BMI was $20.67 \pm 3.91 \mathrm{~kg} / \mathrm{m}^{2}$. In a similar study by Polat et al. (16), the mean height of the male students with an average age of 14 years was $164.09 \pm 8.99 \mathrm{~cm}$, the average body weight was $51.65 \pm 9.13 \mathrm{~kg}$, while the mean of BMI was $19.11 \pm 2.51 \mathrm{~kg} / \mathrm{m}^{2}$. Lovecchio et al. (10) reported that the average BMI value of 14-yearold boys was $19.7 \pm 3.4 \mathrm{~kg} / \mathrm{m}^{2}$.

While the values reported in the literature and the values of Turkish male students in our study were in parallel, it was determined that there were differences between the literature and Iraqi boys. Also, according to FitnessGram norms, it is seen that Turkish male students are in a healthy fitness zone and Iraqi boys to be close to the high-risk fitness area. Therefore, it is thought that the differences between the two groups can be caused by population, socio-economic, nutrition and environmental differences.

The number of errors for Turkish students in the Flamingo Test was $10.45 \pm 3.72$, while the number of errors of Iraqi students was 7.42 \pm 3.81 .

Çelebi (4) reported that the flamingo test results of 12-14 years-old boys who do not play sports were $10.98 \pm 4.00$. Mazlumoğlu (12) revealedit as $12.56 \pm 4.36$ for $11.64 \pm 0.49$ years-old boys. While these values are in line with the results of the Turkish students, it is seen that the values of Iraqi students are lower than these values. The studies in literature reported that the factors such as height, weight, gender,and sport activity affect balance performance (23). Consequently, the results of the Iraqi subjects may be due to the shorter heights from the Turkish boys.

In the present study, the values of sit and reach test of Turkish students were determined as $23.77 \pm 7.16 \mathrm{~cm}$ and the values of Iraqi students were determined as $17.10 \pm 7.36 \mathrm{~cm}$. According to this, a significant difference was found between the two groups in favor of Turkish students $(p<0.05)$. 
Pekel et al. (15) reported the sit and reach flexibility values of 13-year-old male students as $22.9 \pm 7.2 \mathrm{~cm}$. In another study, the sit and reach test flexibility values of male students were reported to be $19.9 \pm 7.7 \mathrm{~cm}$ (13). In the study by Serbes et al. (20), the sit and reach flexibility values of 13-year-old boys were determined as $15.80 \pm 6.235 \mathrm{~cm}$. According to this, it is seen that there are different values in the literature supporting the two group results of our study. Furthermore, it is stated that the sit-up test performance is constant between the ages of 5-8 in males and then decreases with age to the lowest in 12-13 years of age and then increases up to 18 years of age. The low-performance period in men generally are parallel with the elongation of the legs in the adolescence period, the increase in the adolescence period was observed to be in parallel with the increase in height and upper extremity length. It is stated that anatomic and functional changes in joints during adolescence may affect flexibility in this period (11). According to this information, it is thought that the difference in our study may be caused by anatomical differences.

In our study, the mean standing long jump test of Turkish students was $170.97 \pm 25.19 \mathrm{~cm}$ and the mean value of Iraqi students was $152.09 \pm 23.01 \mathrm{~cm}$ in long jump test. There was a significant difference between the two groups in favor of Turkish students $(\mathrm{p}<0.05)$. Koç $(8)$ reported that mean long jump test values of male sedentary students between the ages of $14-16$ was $172.00 \pm 20.00 \mathrm{~cm}$. This study supports the results of Turkish students. We thought that the difference between the two groups in our study for the long jump test may have occurred because Iraqi students are shorter than Turkish students.

In the presentstudy, the mean Hand Gripping Test of Turkish students was $24.57 \pm 4.87 \mathrm{~kg}$ and the mean values of Iraqi students was $24.63 \pm 5.53 \mathrm{~kg}$. There was no significant difference between the two groups ( $p>0.05)$. Kizılakşam (7), reported that the mean hand gripping of male sedentary children with an average age of $13.36 \pm 0.76$ years was $23.95 \pm 8.10 \mathrm{~kg}$. Saygin et al.(19) stated that this number was $25.60 \pm 4.14 \mathrm{~kg}$ for non-sporting male students aged 14. Accordingly, the present results of our study and the information in the literature are similar

In the present study, for the sit and reach test, the mean value of Turkish students was $24.88 \pm 4.22$ and the value of Iraqi students was 23.09 \pm 5.07 . There was no significant difference between the two groups ( $p>0.05)$. Zorba et al.(26) reported that the mean shuttle values of the male sedentary group

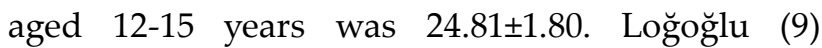
reported the results of the shuttle test of 12-year-old male students as $24.26 \pm 6.68$. Studies in the literature support our work. Based on the fact that sports have an impact on muscular endurance, the difference between the two groups in our study can be thought to be due to the lack of exercise in both groups.

In the present study, the bent arm hang test average of Turkish students (bw: $57.77 \pm 10.71 \mathrm{~kg}$ ) was found to be $12.71 \pm 13.70$ s and the average of the Iraqi students (bw: $38.03 \pm 5.90 \mathrm{~kg}$ ) was $24.69 \pm 15.41 \mathrm{~s}$. A significant difference was found between the two groups in favor of Iraqi students ( $\mathrm{p}<0.05)$. In a study conducted by Bilim et al. (2), the average age was $14,55 \pm 0.50$ years and mean body weight was $55.83 \pm 15.28 \mathrm{~kg}$, and the bent arm hang test average was $14.63 \pm 8.94 \mathrm{~s}$, for the students who do not play sports. In another study, Çelebi (4) reported that the test result of bent arm hang test of non-sporting children with body weight of $41.45 \pm 9.00 \mathrm{~kg}$ in $12-14$ age group was 19.98 \pm 8.00 . According to this information, the reason why Iraqi students have higher values in the arm hanging testmaybethe decrease in bent arm hang test values as the body weight increases.

In our study, the mean 10x5 shuttle run was found to be $34.97 \pm 3.49$ s for Turkish students and $33.46 \pm 3.32 \mathrm{~s}$ for Iraqi students. No significant difference was found between the two groups $(\mathrm{p}>0,05)$.

The mean plate tapping test was found to be 14.94 \pm 2.11 s for Turkish students and 15.74 $\pm 2.74 \mathrm{~s}$ for Iraqi students. No significant difference was found between the two groups $(\mathrm{p}>0.05)$.

Although speed may appear to be an innate trait, the organism has the potential to improve movementspeed with the correct training. Therefore, lack of difference between the groups in the speed feature tested in our study can be explained by the fact that both groups consist of sedentary students.

The mean shuttle run test was found to be $32.84 \pm 6.15 \mathrm{ml} / \mathrm{kg} / \mathrm{min}$ for Turkish students and $34.08 \pm 5.05 \mathrm{ml} / \mathrm{kg} / \mathrm{min}$ for Iraqi students. No significant difference was found between the two groups ( $\mathrm{p}>0.05)$. In the study conducted by Bilim et al. (2), the $\mathrm{VO}_{2}$ max values of non-sporting boys with a mean age of $14.55 \pm 0.50$ years were reported as $33.89 \pm 5.23$. Dağdelen (5) reported that the 
average of $\mathrm{VO}_{2}$ max values was found to be $31.88 \pm$ 4.12 in boys aged 12-14 years. Studies in the literature are parallel with our study. As indicated in the literature, aerobic endurance is only optimally developed over a long period of time (6-8 weeks) when operated with the appropriate method and content (3). It can be thought that the difference between the groups in our study is related to the lack of training of the subjects.

For children in the age of growth, Sports are useful and necessary both in terms of physical healthy physical development and in terms of mental health.

For solving social problems, schools perform an important task. Physical education course is an integral part of general education because it is the only course in which students can be physically active, it offers important opportunities to solve the health problems caused by lack of physical activity (18). Scientific studies have shown that students in this age group need physical activity at least one hour a day to protect their health (6). Şenel (21) found that physical and physiological values of students attending physical fitness activities for 10 minutes in addition to physical education classes were higher than those attending physical education classes only, based on this, he emphasized the need to increase such programs more frequently and comprehensively. Anthropometric measurements and Eurofit, AAHPERD and YFT tests are carried out to determine the physical capacity of children. In our country, studies related to these measurements have been done but, have not yet reached a sufficient number to form a norm yet (17).

The regular realization of these measurements on school-age children allows them to monitor their physical fitness levels so that the criteria for the physical characteristics of the students and the country norms can be established. In addition, these data can make a significant contribution to healthy child rearing, efficient manpower, and selection of qualified sportsmen.

\section{REFERENCES}

1. Baltacı G, Düzgün İ. AdolescentandExercise. Hacettepe UniversityFaculty of HealthSciencesDepartment of PhysicalTherapyandRehabilitation, T. C. Ministry of Health General Directorate of PrimaryHealthCare, Department of NutritionandPhysical Activity, Edition 1, Ankara, 2008. (2)

2. Bilim AS, Çetinkaya C, Dayı A. Examination of thePhysicalFitness of StudentsWho Do Not and Do Not Make Sports Between 12-17 YearsOld, Ondokuz Mayis
UniversityJournal of SportandPerformanceResearch, 2016; 7: 53-60. (5)

3. Bompa TO. AtrenmanTheoryand Management-Periodization. Spor Yayınevi ve Kitabevi, Ankara, 2007. (23)

4. Çelebi F. Comparison of PosturalandBiomotorProperties of 12-14 Age GroupPuberte Sports andSedentaryStudents, Master Thesis, Muğla University, SocialSciencesInstitute, Muğla, 2000. (10)

5. Dağdelen S. Investigation of Effects of PhysiologicalandBiomotorProperties of Training Programs Appliedto 12-14 Age GroupPlayers, Master Thesis, Süleyman Demirel UniversityInstitute of HealthSciences, Isparta, 2013. (22)

6. Janssen I, LeBlanc AG. Systematicreview of thehealthbenefits of physicalactivityandfitness in school-agedchildrenandyouth. International Journal of BehavioralNutritionandPhysical Activity, 2010; 7: 40. (25)

7. Kızılakşam E. 12-14 Age Group Active andNon-Sports (PhysicalEducation Course) Students' Eurofit Test Batteries Application ResultsComparison in Edirne Province Center Primary Schools, Master Thesis, Trakya Üniversitesi Sağlık Bilimleri Enstitüsü, Edirne, 2006. (18)

8. Koc

$$
\text { H. Evaluation }
$$

SomePhysicalandPhysiologicalParameters of the 14-16 Age GroupHandballerandPhysicalEducationStudents in Eurofit Test Batteries, Master Thesis, Gazi University, HealthSciencesInstitute, Department

9. Loğoğlu M. Assessment of thePhysicalFitness of 12-Year-Old School ChildrenwithEurofit Test Batteries, Master Thesis, Selçuk UniversityInstitute of HealthSciences, Department of PhysicalEducationand Sports, Konya, 2002. (21)

10. Lovecchio N, Casolo F, Invernizzı PL, Luca EL. Strength in youngItalianstudents: resultsfromeurofit test andcomparisonamongeuropeandata. Pol. J. SportTourism, 2012; 19: 13-15. (9)

11. Malina RM, Bouchard C. Growth, MaturationandPhysical Activity, Human KineticsBooks, 1991; 391-414. (16)

12. Mazlumoğlu B. Comparison of thePhysicalCondition of Femaleand Male Studentsbetween 10-12 Years of Age andNon-Sports withEurofit Test Batteries, Master Thesis, AtatürkUniversityHealthSciencesInstitute, Erzurum, 2015. (11)

13. Ortega FB, Artero EG, Ruiz J.R, et al,.PhysicalfitnesslevelsamongEuropeanadolescents: the HELENA study. Br J Sports Med., 2011; 45(1): 20-9. (14)

14. Özer DS, Özer MK. Motor Development in Children. 6th edition, Nobel Yayın Dağıtım, Ankara, 2007. (4)

15. Pekel HA, Balcı ŞS, Arslan Ö, ve ark,.Evaluation of performance-relatedphysicalfitness test resultsandsomeantrepometriccharacteristics of athleticchildren. Kastamonu EducationJournal, 2007; 15 (1): 427-38. (13)

16. Polat $Y$, Çınar V, Şahin $M$, Pepe O. Examination of theAnthropometricProperties of 14-Year-Old ChildrenwithPhysicalFitnessLevels, i̇.Ü. Journal of SportSciences, 2003, (11) 3 (ÖS): 127-30. (8) 
17. Salih E, Oğuz H. Investigation of PhysicalPerformanceCharacteristics of FamilyChildrenwithDifferentSocio-Economic Level in Bursa Province, UludagUniversityFaculty of EducationJournal, 2009; 22: 279-92. (27)

18. Sallis JF, McKenzie TL, Eltder JP, Hoy PL. SexAndEthnicDifference In ChildrensPhysical Activity DiscrepanciesBetweern Self - RepotAndObjectiveMeasures. PediatricExerciseScience (Champaign III), 1998, 10;277-84. (24)

19. Saygın E, Karacabey K, Saygın Ö. Investigation of Physical Activity andPhysicalFitnessElements in Children, International Journal of Human Sciences, 2011; 8(2): 921-35. (19)

20. Serbes Ş, Yurdakul HÖ, Şahin G. Flexibilitynormsforboysandgirlsaged 8-13 years; CanakkaleSample, 1st International Childrenand Sports Congress, 19-21 April, Kibris, 2010. (15)

21. Şenel Ö. TheEffects of PhysicalFitness Activity on PhysicalandPhysiologicalParameters of PrimaryPhysicalEducation Course Curriculum. Gazi Journal of PhysicalEducationandSportSciences, 1998; 3: 27-34. (26)

22. Tamer K. PhysicalPhysiologicalPerformanceMeasurementand Evaluation in Sport. Bağırgan Yayınevi, Ankara, 2000. (6)
23. Tekin YS. Investigation of BalancePerformance of Athletes, WrestlingandTaekwondoBranches, Master Thesis, SelcukUniversityInstitute of HealthSciences, Konya, 2016. (12)

24. Werner WK, Hopkins KH, Hopkins DR. A comparison of the sit andreachandthemodified sit andreach in themeasurement of flexibility in women. ResearchQuarterlyForExerciseAndSport, 1992; 63(2): 191-5. (3)

25. Ziyagil MA, Tamer K, Zorba E, Uzuncan S, Uzuncan H. Evaluation of PhysicalFitnessandAnthropometricProperties of Male Elementary School Studentsbetween 10-12 Years of agebymeans of Eurofit Test BatteryAccordingto Age GroupsandSportHabits, Journal of PhysicalEducation, 1996; $1: 20-8 .(7)$

26. Zorba E, Ziyagil $M$, Çolak $H$, ve ark,.Comparison of theAnthropometricandPhysicalFitnessValues of 12ası15 Age GroupSockswithSedentaryGroup.

Hacettepe University,ScienceandTechnology Football Magazine, 1995; s, 40. (20)

27. Zorba E, Saygın Ö. Physical Activity andPhysicalFitness, Perspektif Matbaacılık Tasarım Tic. Ltd. Şti., Ankara, 2017. (1) 